\title{
Spatial and temporal variations of recruitment in the tube worm Riftia pachyptila on the East Pacific Rise $\left(9^{\circ} 50^{\prime} \mathrm{N}\right.$ and $\left.13^{\circ} \mathrm{N}\right)$
}

\author{
Eric Thiébaut ${ }^{1, *}$, Xavier Huther ${ }^{2}$, Bruce Shillito $^{2}$, Didier Jollivet ${ }^{3}$, Françoise Gaill ${ }^{2}$ \\ ${ }^{1}$ Laboratoire d'Océanographie de Villefranche/mer, CNRS UMR 7093 and ${ }^{2}$ Laboratoire de Biologie Marine, CNRS UMR 7622, \\ Université Paris VI, Bâtiment A, Case 6, 4 Place Jussieu, 75252 Paris cedex 05, France \\ ${ }^{3}$ Station Biologique de Roscoff, CNRS UMR 7127, Université Paris VI, Place Georges Teissier, BP 74, 29682 Roscoff cedex, France
}

\begin{abstract}
The giant vestimentiferan tubeworm Riftia pachyptila is one of the most abundant and ecologically important species at deep-sea hydrothermal vents along the East Pacific Rise (EPR). Clumps of $R$. pachyptila could indeed be viewed as one of the most frequent habitats for the fauna typifying the eastern Pacific hydrothermal vent sites and thus deserve specific attention, as their dynamics are likely to control the spatial and temporal evolution of numerous vent species. As a consequence, population structure and recruitment of $R$. pachyptila were studied from samples taken at different vent localities during 2 EPR surveys in 1996 and 1997. In 1996, 3 samples were collected within and between the hydrothermal vent fields $13^{\circ} \mathrm{N}$ and $9^{\circ} 50^{\prime} \mathrm{N}$ to assess the spatial coherence of recruitment. In 1997, a huge number of additional specimens were collected at $9^{\circ} 50^{\prime} \mathrm{N}$ from a single vent site at 3 successive dates over 22 d to determine how growth rate may affect the temporal variability of population structure at a small spatial scale. Size-frequency analyses were performed using the vestimentum width as a biometric index. Inter-site comparisons revealed that size-frequency distributions did not differ significantly within a vent field suggesting the synchronisation of recruitment locally (i.e. a few km). By contrast, population structure strongly differed between the 2 vent fields in response to local variations in time of larval supply and/or reproductive activity. The size-frequency histograms of the 3 samples collected in 1997 displayed a regular polymodal structure reflecting a discontinuous recruitment in time. The presence of a large number of small individuals attached to the tube of conspecific larger ones suggested that biological cues associated with Riftia may promote habitat selection by settlers. Differences between the modal vestimentum width of each population 'cohorts' from the 3 temporal samples were significant and could result from either a growth rate heterogeneity in response to local environmental variations or to population ageing. According to this 2nd assumption, growth rate was estimated from the evolution of the 5 'cohorts' found over $22 \mathrm{~d}$. Our data suggested that $R$. pachyptila exhibits: (1) a high yearly tube growth rate (estimated to about $160 \mathrm{~cm} \mathrm{yr}^{-1}$ ); (2) a high individual mortality rate; and (3) a high population turnover, all of which are the characteristics of an opportunistic species.
\end{abstract}

KEY WORDS: Hydrothermal vents $\cdot$ Populations $\cdot$ Recruitment $\cdot$ Settlement $\cdot$ Growth rate $\cdot$ Vestimentiferans $\cdot$ Riftia pachyptila

Resale or republication not permitted without written consent of the publisher

\section{INTRODUCTION}

The deep-sea hydrothermal vent fauna consists of dense benthic communities supported by high chemosynthetic primary productivity through endosymbiosis of a few key species. Its habitat is characterised by 3

*E-mail: eric.thiebaut@snv.jussieu.fr important environmental attributes which govern communities composition, distribution and dynamics (Tunnicliffe 1991): (1) the harsh physical and chemical conditions experienced by the vent fauna impose specific physiological adaptations to become sulphide specialists and thus lead to the high level of endemism already observed over the ridge systems (Jollivet 1996); (2) vent sites are patchily distributed over oceanic ridges with inter-site distances ranging from a few 
metres to 100s of metres within a given vent field, and inter-field distances ranging from 100 s to 1000 s of kilometres between disjunct segments of a ridge; and (3) the high temporal variability of hydrothermal activity due to tectonic events and heat convection through the oceanic crust induces a high site turnover that may vary in duration from years to decades on fast spreading ridges (Watremez \& Kervevan 1990, Lalou 1991). Thus, vent fauna have to adapt to an ephemeral and unpredictable habitat, changes of which are responsible for a sequence of extinction and rapid colonisation.

Although the understanding of processes involved in the establishment and maintenance of benthic populations in such an environment has been recognised as a major goal of hydrothermal vent ecology (Tunnicliffe 1991), life histories of vent organisms remain poorly documented due to the lack of long-term data (over yr) that arose from difficult access to deep-sea hydrothermal habitats (Tyler \& Young 1999). Larval dispersal has been inferred from (1) the larval development (e.g. Marsh et al. 2001); (2) the size of prodissoconch shells of mollusks adults (e.g. Lutz et al. 1984); (3) the larval physiology (e.g. Pond et al. 1997); (4) the spatial distribution of larvae in relation to hydrodynamic processes (e.g. Mullineaux et al. 1995, Kim \& Mullineaux 1998); and (5) indirect measurements of gene flow between distant sites (e.g. Black et al. 1994, Jollivet et al. 1995). On the other hand, discrete benthic samples were used to determine reproductive traits of organisms and to characterise population structure. Population structures have been assessed through size-frequency analysis for polychaetes and bivalves, providing information on the recruitment patterns of hydrothermal species and mechanisms by which populations renew or are founded. Discontinuous recruitment has been reported for most species studied to date including the ampharetid polychaete Amphisamytha galapagensis (McHugh \& Tunnicliffe 1994), the alvinellid polychaetes Alvinella pompejana, A. caudata, Paralvinella grasslei and P. palmiformis (McHugh 1989, Jollivet 1993, Zal et al. 1995), serpulid worms and the vestimentiferan Tevnia jerichonana (Jollivet 1993), mytilid bivalves and polynoid commensals (Comtet \& Desbruyères 1998, Jollivet et al. 2000). Conversely, McHugh (1989) hypothesised a continuous recruitment of the polychaete Paralvinella pandorae. Discontinuous recruitment may be related to the occurrence of reproductive cycles in marine invertebrates. For Paralvinella grasslei, Zal et al. (1995) hypothesised that tidal signal, which is clearly periodic in the hydrothermal ecosystem, is the most likely external factor coordinating the reproductive cycle of individuals within vent sites and fields. Conversely, Comtet \& Desbruyères (1998) suggested that recruitment of mytilid bivalves on the Azorean triple junction may be syn- chronised between 2 vent fields separated by a distance of $60 \mathrm{~km}$, and proposed that pelagic fluxes could trigger the emission of gametes and/or the settlement of larvae.

The giant vestimentiferan tube worm Riftia pachyptila Jones, 1981 (herafter called Riftia for convenience) has been reported from the Guaymas Basin $\left(27^{\circ} \mathrm{N}\right)$ to the Galapagos Rift $\left(0^{\circ} 50^{\prime} \mathrm{N}\right)$ in the vigorous diffusive flow zone of hydrothermal vents. As it is one of the most widespread, abundant and ecologically important species at vents of the east Pacific (Jollivet 1993, Shank et al. 1998, Shillito et al. 1999), its life cycle is one of the most studied among vent species in recent years. Van Dover (1994) reported in situ observations of discontinuous bursts of gamete emission over Riftia thickets at $13^{\circ} \mathrm{N} / \mathrm{EPR}$. While Cary et al. (1989) hypothesised that fertilisation may take place within the female's vestimentum cavity, Gardiner \& Jones (1985) observed individual spermatozoa close to mature oocytes in the female genital tract, raising the possibility of internal fertilisation. However, such fertilisation could occur just by chance, as huge amounts of sperm masses seem to fall down onto the tubes after emission in vestimentiferans (Southward \& Coates 1989). Whatever the fertilisation mode, larval development of vestimentiferans includes a free-living, nonfeeding trochophore larvae (Young et al. 1996, Marsh et al. 2001). From metabolic rates measurements, the average larval lifespan was estimated to be $38 \mathrm{~d}$ (Marsh et al. 2001). These data and the characteristics of current flows suggested that eggs and embryos could be entrained in the neutrally buoyant plumes of active venting sites and subsequently dispersed over distances rarely exceeding $100 \mathrm{~km}$. However, based on gene flow analysis, Black et al. (1994) indicated a high rate of dispersal for Riftia. From a temporal survey of the $13^{\circ}$ N/EPR communities between 1984 and 1990, Jollivet (1993) suggested that the vestimentiferan $\mathrm{TeV}$ nia jerichonana is one of the first colonisers of the new vent sites and is subsequently replaced by $R$. pachyptila. From a long-term study of faunistic succession at newly formed vent sites of the $9^{\circ} 50^{\prime}$ N/EPR, Shank et al. (1998) confirmed this hypothesis and highlighted that vestimentiferan tube worms have a very high rate of colonisation; pioneering colonies of Tevnia jerichonana were established within 11 mo and subsequently replaced by dense clumps of Riftia within 32 mo. While these authors put forward that the vestimentiferan succession was correlated to a temporal modification of geochemical conditions, Mullineaux et al. (2000) argued that the settlement of Riftia may be facilitated by the occurrence of Tevnia jerichonana. These previous studies on the Riftia life cycle raise different questions that are addressed in this study: (1) Is recruitment of Riftia discontinuous and if it is, is it periodic? (2) What 
are the spatial scales of coherence of the recruitment? (3) How can growth rate influence population dynamics?

To answer these questions, the aim of the present work was to examine the population structure of Riftia from samples collected both from different vent localities and different periods of time on the EPR in 1996 and 1997. The processes involved in the recruitment and population dynamics of the species are discussed. Particular attention was given to the influence of growth rate in shaping population structure at microspatial and temporal scales.

\section{MATERIALS AND METHODS}

Study area and sampling. As assessing population dynamics in a patchy environment requires an accurate reference to spatial scales, the terminology defined by Chevaldonné et al. (1997) has been used in the present work.

Samples of vestimentiferan tube worms were col-

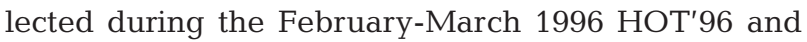
November-December 1997 EPR'97 oceanographic surveys conducted on hydrothermal vents at $9^{\circ} 50^{\prime} \mathrm{N}$ and $13^{\circ} \mathrm{N}$ on the EPR. Three previously described sites were sampled during the 1st survey: Genesis $\left(12^{\circ} 48.63^{\prime} \mathrm{N}, \quad 103^{\circ} 56.41^{\prime} \mathrm{W}\right)$, Parigo $\left(12^{\circ} 48.57^{\prime} \mathrm{N}\right.$, $\left.103^{\circ} 56.41^{\prime} \mathrm{W}\right)$ and $\mathrm{Qvent}\left(9^{\circ} 50.78^{\prime} \mathrm{N}, 104^{\circ} 17.59^{\prime} \mathrm{W}\right)$, while 1 site was sampled during the 2 nd survey: Riftia Field $\left(9^{\circ} 50.75^{\prime} \mathrm{N}, 104^{\circ} 17.57^{\prime} \mathrm{W}\right)$. Vestimentiferans were collected using the arms of the French submersible
'Nautile' (HOT'96) or the American submersible 'Alvin' (EPR'97) and brought back to the surface in an insulated basket. For the Hot'96 survey, samples from 1 vent site consisted of a pooled mixing of individuals collected during different dives at the same site. For the EPR'97 survey, 3 samples were collected at the same vent site during 3 distinct dives at about $10 \mathrm{~d}$ intervals. On board, vestimentiferans were preserved with $10 \%$ formalin in seawater.

Determination of a biometric index. The choice of a biometric index representative of the animal size was determined according to 3 criteria. The variable has to be (1) easily measurable; (2) unaffected by formalin fixation; and (3) related to the animal's growth. The 2nd criterion was defined in order to be applied either to fixed material used in ecological studies or to fresh material used in physiological studies.

Nine easily measurable body dimensions (i.e. total body length, plume length, vestimentum length, trunk length, opisthosome length, plume width, vestimentum width, trunk width, opisthosome width) were measured to the nearest $0.1 \mathrm{~mm}$ with a vernier caliper for widths and to the nearest $0.5 \mathrm{~mm}$ with a ruler for lengths from a subsample of 56 individuals collected in 1997 (Fig. 1). On each individual, measurements were carried out, first, just after recovery on board and, second, 6 mo after the fixation. Finally, individuals from our subsample were dried at $60^{\circ} \mathrm{C}$ to a constant weight and subsequently weighed to the nearest $0.1 \mathrm{mg}$ to obtain worm dry weight (DW).

Size-frequency histograms and sex ratio. The vestimentum width was measured for a total of 188 fresh or

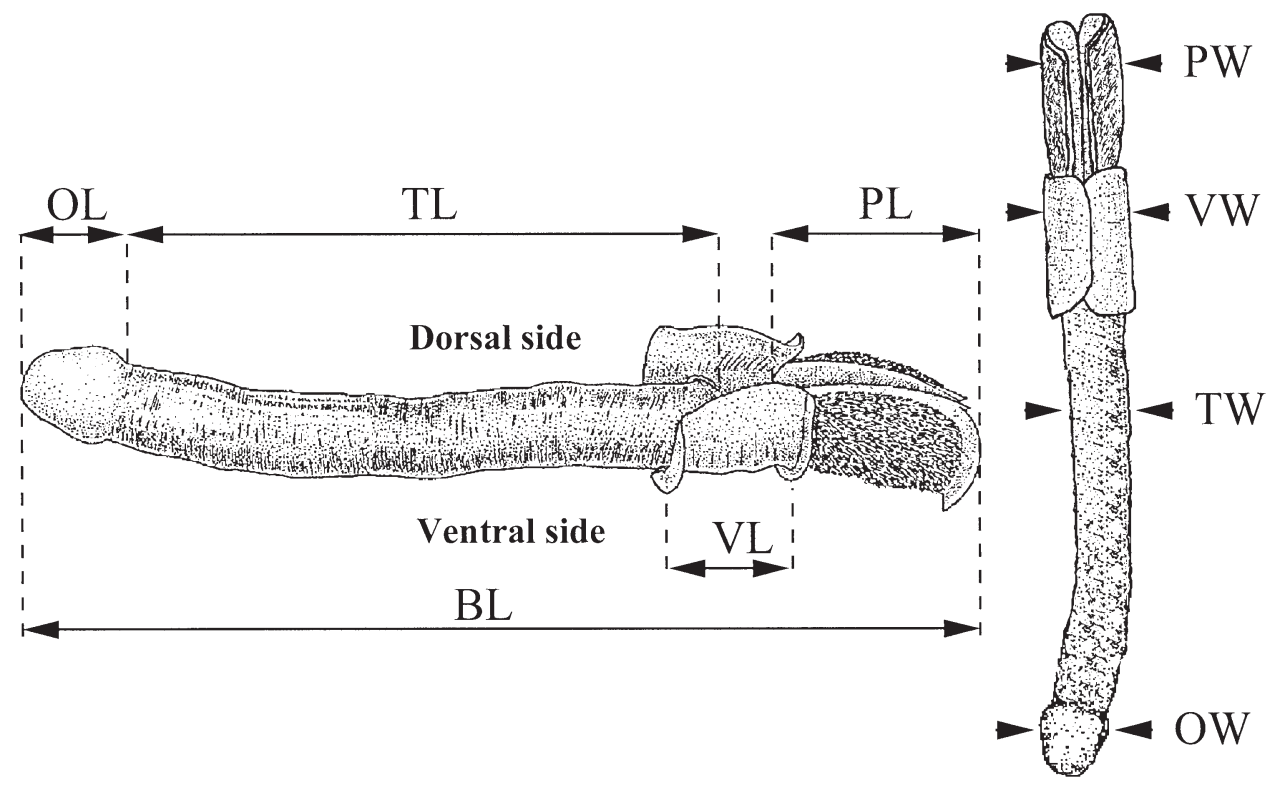

Dorsal side
Fig. 1. Riftia pachyptila. Biometric measurements carried out on Riftia pachyptila individuals. BL: total body length; PL: plume length; VL: vestimentum length; TL: trunk length; OL: opisthosome length; PW: plume width; VW: vestimentum width; TW: trunk width; OW: opisthosome width 
fixed individuals and 1608 fixed individuals in 1996 and 1997, respectively. To analyse the population structure, sizefrequency histograms were plotted using a $2 \mathrm{~mm}$ size-class interval for 1996 data and $0.5 \mathrm{~mm}$ for 1997 data. This interval was chosen according to 3 criteria: (1) most size classes must have at least 5 individuals; (2) the number of adjacent empty classes must be minimised; and (3) the interval has to be larger than the error on measurements. Size-frequency histograms were smoothed using a weighted moving average at the 3rd order to rule out spurious peaks (Frontier \& Pichod-Viale 1991, Zal et al. 1995, Comtet \& Desbruyères 1998, Jollivet et al. 2000). Modal decomposition of size-frequency histograms was performed using the NORMSEP program (Tomlinson 1971) adapted by Gros \& Cochard (1978), assuming a Gaussian distribution of vestimentum width within each cohort. The program discriminates overlapping Gaussian components using the method of Bhattacharya (1967) and calculates the principal parameters of each component (i.e. average, standard deviation and frequency) according to Hasselblad's method (1966).

Individuals were sexed according to the presence of ciliated ridges associated with the paired genital apertures of males which are present at the posterior third of the dorsal surface of vestimentum (Jones 1981). Only individuals with a vestimentum width $\geq 5 \mathrm{~mm}$ were considered. The sex ratios of samples were compared to the expected 1:1 male:female sex ratio using a $\chi^{2}$ goodness of fit test (Sokal \& Rohlf 1981).

\section{RESULTS}

\section{The biometric index}

Linear regressions calculated between fresh and fixed measurements allow us to detect formalin-shrinkage effects as soon as the slope and the intercept of regressions differ significantly from 1 and 0 , respectively (Table 1). From these analyses, only 4 body measurements were left unchanged by the formalin fixation and could be used as a biometric index: plume length, plume width, vestimentum width and opisthosome width.

Calculations of allometric equations showed that the best fit was obtained for correlations between the plume length or the vestimentum width and the worm DW (Fig. 2). As body extremities may be partly damaged during sampling or by predation, the vestimentum width was retained as biometric index for the present study.


Fig. 2. Riftia pachyptila. Logarithm-transformed relationship between (A) the vestimentum width (VW) or (B) the plumelength (PL), and the total dry weight (DW) of the tubeworm

\section{Data from the HOT'96 survey}

Vestimentum width ranged from $0.58 \mathrm{~mm}$ for smallest individuals to $31.80 \mathrm{~mm}$ for largest ones (Table 2). Due to the small size of samples, no modal decomposition of the size-frequency histograms was performed. However, size-frequency distributions were compared to a normal distribution using a Kolmogorov-Smirnov 1-sample test 
Table 2. Riftia pachyptila. Sample size and vestimentum width range of $R$. pachyptila individuals collected in February-March 1996 and in November-December 1997 from different hydrothermal vent sites of $13^{\circ}$ N/EPR and 9 50' N/EPR

\begin{tabular}{|c|c|c|c|c|c|c|c|}
\hline \multirow{2}{*}{$\begin{array}{l}\text { Oceanographic } \\
\text { survey }\end{array}$} & \multirow[t]{2}{*}{ Date } & \multirow[t]{2}{*}{ Vent area } & \multirow[t]{2}{*}{ Vent site } & \multirow[t]{2}{*}{ Sample size } & \multicolumn{3}{|c|}{ Vestimentum diameter (mm) } \\
\hline & & & & & Range & Mean & $\mathrm{SD}$ \\
\hline HOT'96 & Feb-Mar 96 & $13^{\circ} \mathrm{N}$ & Genesis & 52 & $0.58-30.00$ & 12.79 & 10.81 \\
\hline $\mathrm{HOT}^{\prime} 96$ & Feb-Mar 96 & $13^{\circ} \mathrm{N}$ & Parigo & 64 & $0.70-31.80$ & 14.67 & 9.00 \\
\hline $\mathrm{HOT}^{\prime} 96$ & Feb-Mar 96 & $13^{\circ} \mathrm{N}$ & Genesis + Parigo & 116 & $0.58-31.80$ & 13.83 & 9.85 \\
\hline $\mathrm{HOT}^{\prime} 96$ & Feb-Mar 96 & $9^{\circ} 50^{\prime} \mathrm{N}$ & Q vent & 72 & $7.23-28.00$ & 16.98 & 5.41 \\
\hline EPR'97 & 27 Nov 97 & $9^{\circ} 50^{\prime} \mathrm{N}$ & Riftia Field & 883 & $0.34-21.67$ & 5.93 & 3.94 \\
\hline EPR'97 & 7 Dec 97 & $9^{\circ} 50^{\prime} \mathrm{N}$ & Riftia Field & 345 & $0.60-16.51$ & 6.37 & 3.90 \\
\hline EPR'97 & 19 Dec 97 & $9^{\circ} 50^{\prime} \mathrm{N}$ & Riftia Field & 390 & $0.29-21.07$ & 8.26 & 4.98 \\
\hline
\end{tabular}

(Sokal \& Rohlf 1981). When pooling samples from Genesis and Parigo, this test demonstrated that the sizefrequency distribution of vestimentiferans from the $13^{\circ} \mathrm{N}$ vent field differed significantly from a normal distribution $(\mathrm{p}<0.05)$ while that of the $9^{\circ} 50^{\prime} \mathrm{N}$ vent field ( $Q$ vent site) did not ( $p>0.05)$. The sample from the $Q$ vent site had a smaller size range and was exclusively made of individuals having a vestimentum width larger than $7 \mathrm{~mm}$ (Table 2, Fig. 3). By contrast, samples from the Genesis and Parigo sites exhibited a greater size range. Samples were mainly subdivided into 2 size groups of small individuals (vestimentum width $<5 \mathrm{~mm}$ ) and large individuals (vestimentum width $>15 \mathrm{~mm}$ ) (Fig. 3). The size-

$13^{\circ} \mathbf{N}$

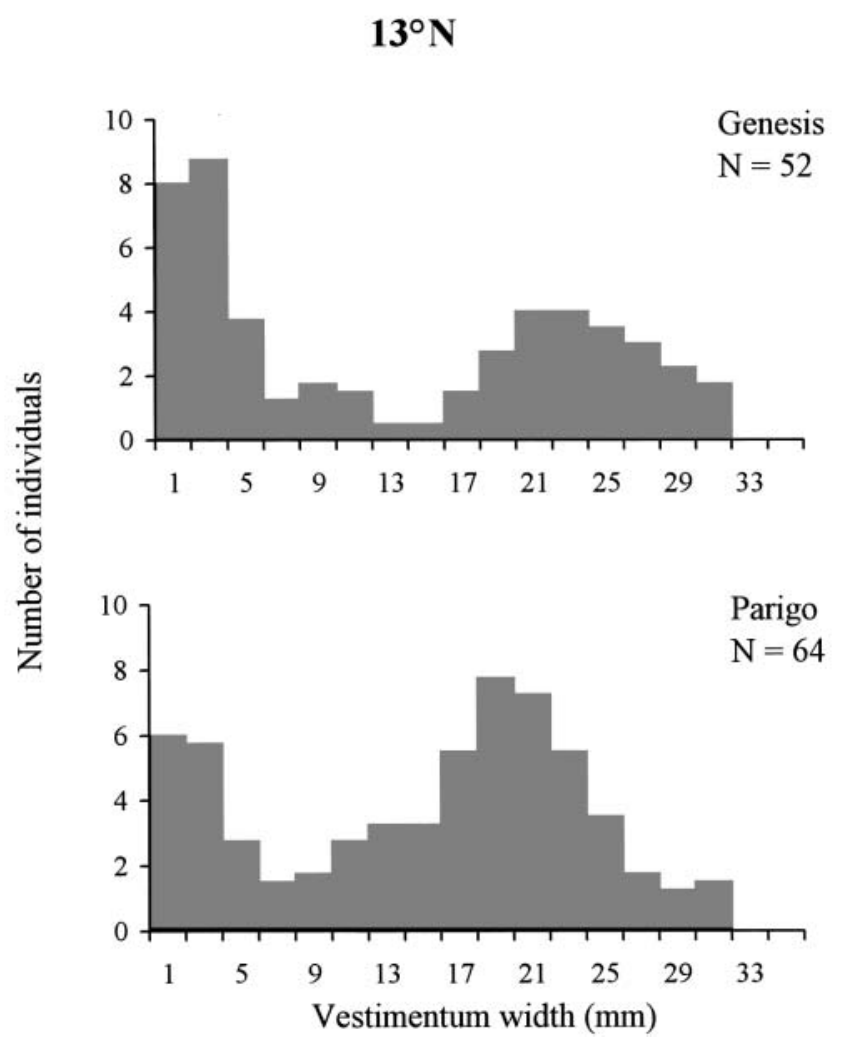

frequency distributions did not differ significantly between the Genesis and Parigo sites (KolmogorovSmirnov 2-samples test, $\mathrm{p}>0.05$ ).

\section{Data from the EPR'97 survey}

For the 3 samples of Riftia collected from the Riftia Field vent site, the vestimentum width ranged from 0.29 to $21.67 \mathrm{~mm}$ (Table 2). All the size-frequency distributions significantly differed from the normal distribution (Kolmogorov-Smirnov 1-sample test, p < 0.05) and displayed a regular polymodal structure (Fig. 4).
Fig. 3. Riftia pachyptila. Size-frequency histograms of the vestimentum width from the $3 R$. pachyptila samples collected in February-March 1996 on vent sites at $13^{\circ} \mathrm{N} / \mathrm{EPR}$ (Genesis and Parigo) and $9^{\circ} 50^{\prime} \mathrm{N} / \mathrm{EPR}$ (Q vent). $\mathrm{N}=$ sample size 

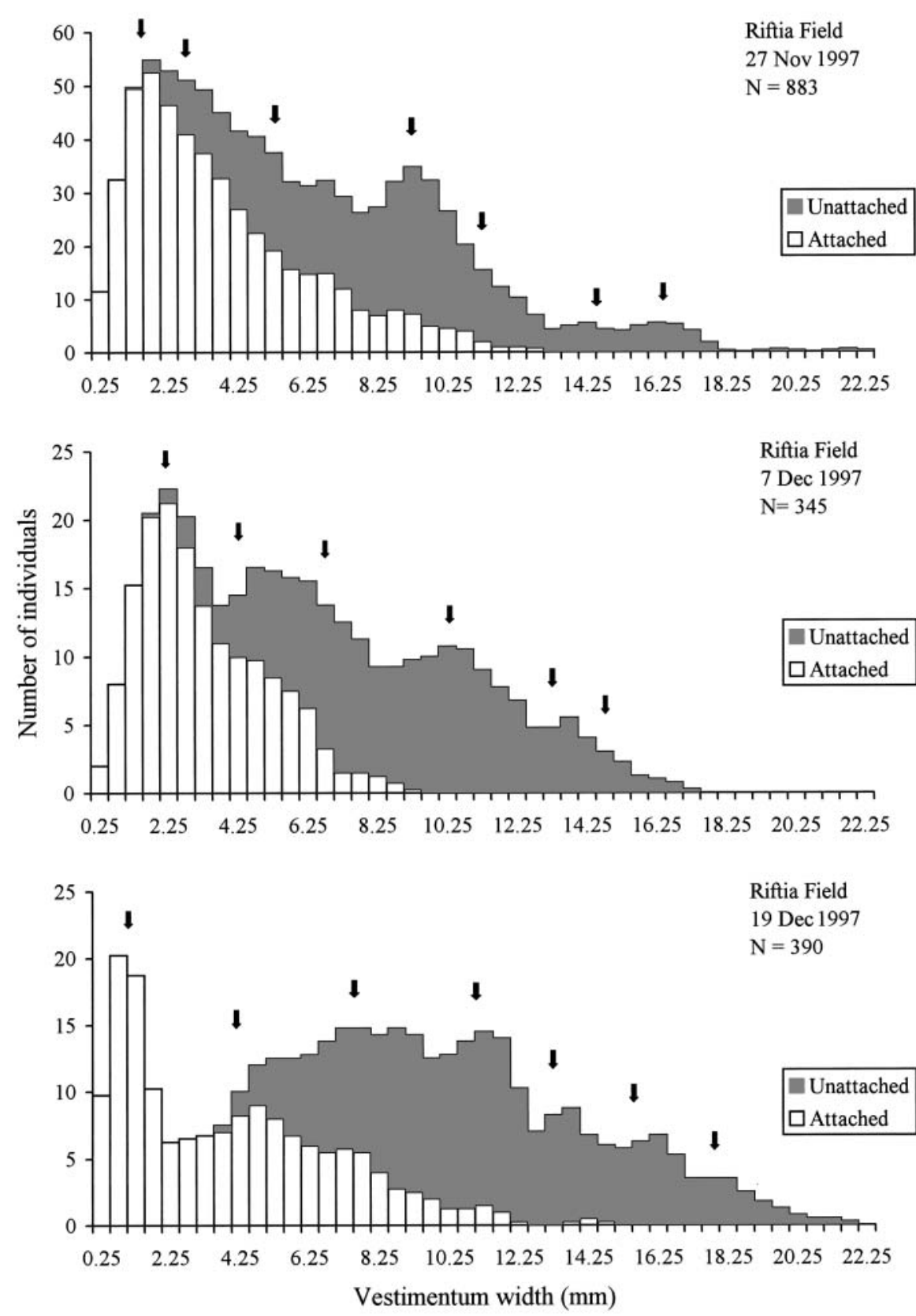

Fig. 4. Riftia pachyptila. Sizefrequency histograms of the vestimentum width from the $3 R$. pachyptila samples collected in November-December 1997 on the Riftia Field hydrothermal vent site $\left(9^{\circ} 50^{\prime} \mathrm{N} / \mathrm{EPR}\right) . \mathrm{N}=$ sample size. $\boldsymbol{\downarrow}=$ mean of each modal component determined using the NORMSEP software. 'Attached' and 'Unattached' refer to individuals fixed on a Riftia tube or to the basaltic substrate, respectively

Size-frequency histograms are all log-normal shaped suggesting that a high mortality rate is likely to occur amongst small individuals. Comparisons between the 3 samples also indicated significant differences in their size-frequency distributions (Kolmogorov-Smirnov 2 -samples test, $\mathrm{p}<0.05)$. The modal decomposition of the size-frequency distributions indicates the occurrence of 6 Gaussian components for the sample from 7 December and 7 components for the samples from 27 November and 19 December. The characteristics of each component are given in Table 3. Although the relative importance of each mode varies from one sample to another, all samples were mainly composed of individuals belonging to the 4 first modes. Largest individuals were sparse and formed only a small percentage of each sample. One can note that the sample from 19 December displayed the highest proportion of newly settled individuals (vestimentum width $<1.5 \mathrm{~mm}$ ).

Within each sample, all individuals were either attached to another tube of Riftia (hereafter called 'attached individuals') or not (hereafter called 'unattached individuals') (Fig. 5). Unattached individuals could have been anchored to the basaltic substrate or 
Table 3. Riftia pachyptila. Modal decomposition of size-frequency distributions of the vestimentum width in the $3 R$. pachyptila samples collected in November-December 1997 from the Riftia Field hydrothermal vent site. The modal decomposition was performed using NORMSEP software. The different components are numbered according to the occurrence of a massive recruitment event between 7 and 19 December 1997. See 'Discussion' for explanation

\begin{tabular}{|c|c|c|c|c|c|c|c|c|}
\hline \multirow[t]{2}{*}{ Date } & \multicolumn{8}{|c|}{ Component } \\
\hline & 0 & 1 & 2 & 3 & 4 & 5 & 6 & 7 \\
\hline \multicolumn{9}{|c|}{27 November } \\
\hline \multicolumn{9}{|c|}{$\chi^{2}=2.932 ; \mathrm{p}=0.999 ; \mathrm{df}=14$} \\
\hline Proportion & - & 13.61 & 22.41 & 30.52 & 21.13 & 8.35 & 1.67 & 2.31 \\
\hline Average (mm) & - & 1.29 & 2.80 & 5.33 & 9.08 & 11.23 & 14.64 & 16.58 \\
\hline $\mathrm{SD}(\mathrm{mm})$ & - & 0.57 & 0.94 & 1.50 & 1.35 & 1.65 & 0.80 & 0.71 \\
\hline \multicolumn{9}{|l|}{7 December } \\
\hline \multicolumn{9}{|c|}{$\chi^{2}=0.892 ; p=1.000 ; \mathrm{df}=12$} \\
\hline Proportion & - & 24.07 & 22.04 & 24.23 & 19.94 & 8.28 & 1.44 & - \\
\hline Average (mm) & - & 1.97 & 4.18 & 6.58 & 10.20 & 13.25 & 15.01 & - \\
\hline $\mathrm{SD}(\mathrm{mm})$ & - & 0.79 & 1.24 & 1.33 & 1.37 & 1.43 & 1.15 & - \\
\hline \multicolumn{9}{|l|}{19 December } \\
\hline \multicolumn{9}{|c|}{$\chi^{2}=3.486 ; p=0.999 ; \mathrm{df}=18$} \\
\hline Proportion & 14.05 & 14.85 & 31.40 & 17.63 & 9.78 & 7.47 & 4.82 & - \\
\hline Average (mm) & 0.99 & 3.94 & 7.45 & 10.84 & 13.08 & 15.68 & 18.02 & - \\
\hline $\mathrm{SD}(\mathrm{mm})$ & 0.50 & 1.49 & 1.74 & 1.33 & 1.48 & 1.33 & 1.59 & - \\
\hline
\end{tabular}

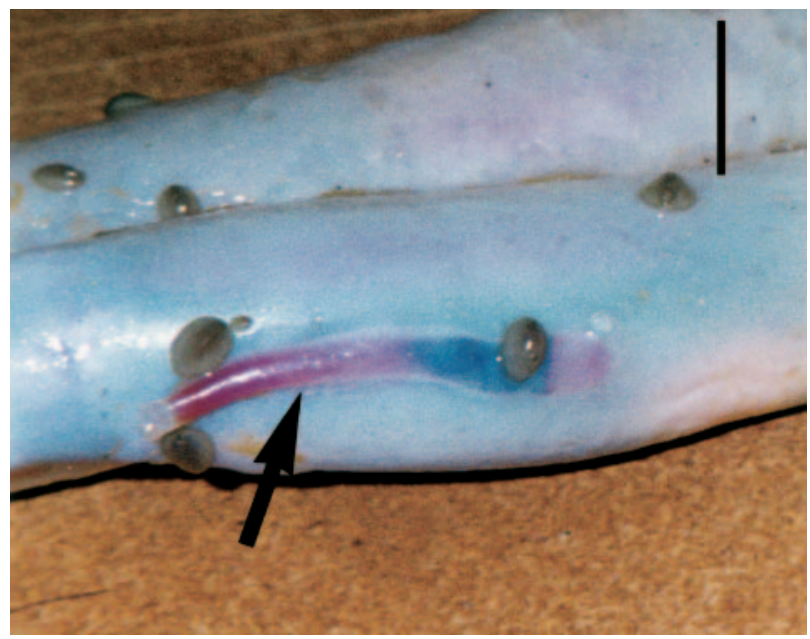

Fig. 5. Riftia pachyptila. A young individual that was attached to the tube of a large individual. The arrow indicates the young individual. Scale bar $=2 \mathrm{~cm}$

detached from a tube during the sampling process. Although sampling bias could not be quantified, attached individuals were abundant (i.e. 40.8 to $54.4 \%$ of collected individuals within each sample adhered to another tube). Moreover, size-frequency distributions showed that all the smallest individuals were attached (Fig. 4). The chance of being attached decreased as the worm size increased. Thus, no attached individual was observed for a vestimentum width $>14.5 \mathrm{~mm}$.

The sex ratios showed significant deviations from a 1:1 male:female ratio for samples from 27 November and 7 December, and no deviation for the sample from 19 December (Table 4). This deviation was found to vary in favour of females in the 1st sample and in favour of males in the 2nd one. After pooling the 3 samples, no significant difference was detected.

\section{DISCUSSION}

Dispersal is one of the most fundamental issues regarding processes involved in the maintenance of vent-endemic species populations and the colonisation of new vent habitat. For Riftia, dispersal ability inferred from population genetics analyses or from larval development and current knowledge about the ridge hydrodynamics is still debatable. Using allozyme data, Black et al. (1994) suggested that larval exchanges are maximal between neighbouring populations, and long-distance dispersal between adjacent

Table 4. Riftia pachyptila. Observed deviations from the expected 1:1 male:female sex ratio in the $3 R$. pachyptila samples collected in November-December 1997 from the Riftia Field hydrothermal vent site. Level of significance: ${ }^{*} \mathrm{p}<0.05$

\begin{tabular}{|lcccc|}
\hline & 27 Nov & 7 Dec & 19 Dec & $\begin{array}{c}\text { Overall } \\
\text { observations }\end{array}$ \\
\hline Undetermined & 490 & 164 & 113 & 767 \\
Females & 238 & 78 & 129 & 445 \\
Males & 196 & 106 & 149 & 451 \\
$\chi^{2}$ & $4.065^{*}$ & $4.571^{*}$ & 1.439 & 0.055 \\
\hline
\end{tabular}


ridge axes could occur. Conversely, an estimation of Riftia larval lifespan ranging between 34 and $44 \mathrm{~d}$ allowed Marsh et al. (2001) to argue that along-ridge dispersal is restricted to $10 \mathrm{~s}$ of $\mathrm{km}$ and rarely exceeds $100 \mathrm{~km}$. However, these studies do not refer to the same temporal scales: while results from the former integrate 1000s of generations and impose effective settlements, results from the latter are restricted to 1 generation and do not take into account the fact that exchanged larvae have to live long enough to reproduce successfully in the home population. As a consequence, such studies are not comparable. Jollivet et al. (1999) indeed demonstrated that long-term dispersal is not a prerequisite to maintain high levels of gene flow at the ridge scale. However, an alternative to testing how larval dispersal affects population structures is to assess the dynamics over a spatial hierarchy, since population dynamics and in vitro larval development infer processes over a period of time which is limited to 1 generation.

Despite a limited dataset, our preliminary results obtained from the 1996 samples tend to support the hypothesis of a lack of consequent long-distance transport of larvae. The populations at $13^{\circ} \mathrm{N} / \mathrm{EPR}$ were composed of small and large individuals at both sampled vent sites. Although no modal analysis was performed, the presence of small individuals at the Genesis and Parigo sites suggested that a recent recruitment event occurred at each site and that a synchrony of the recruitment could be considered within a vent field at a scale of $\mathrm{km}$. By contrast, the unique population studied at $9^{\circ} 50^{\prime}$ N/EPR included only medium and large individuals. The absence of young recruits at this site seems to indicate a lack of synchrony of reproduction and recruitment between $9^{\circ} 50^{\prime} \mathrm{N}$ and $13^{\circ} \mathrm{N}$ vent sectors that suggest no massive exchanges of larvae at this spatial scale.

The size-frequency distributions of the 3 Riftia samples collected in 1997 at Riftia Field are clearly polymodal, which indicates a discontinuous recruitment as previously observed by Jollivet (1993) for the different species of vestimentiferan tubeworms of the EPR at $13^{\circ} \mathrm{N}$ (i.e. Riftia, Oasisia spp. and Tevnia jerichonana) and by Tunnicliffe (1991) for Ridgeia spp. From these data, one striking observation is that the shape of size histograms is greatly skewed towards small individuals suggesting that vestimentiferans undergo high mortality rates after settlement. This could be due to crab and fish predation and/or intra- and interspecific competition.

The modal decomposition of size-frequency histograms shows that each distribution is composed of a mixture of 6 or 7 Gaussian components assumed to represent successive cohorts. Different hypotheses may be formulated to explain differences in the number and the position of size groups between samples. First, it may result from a bias in the sampling due to either a possible selectivity of the arm of the submersible towards specific size classes or a spatial segregation of the sizes according to their position within a vent site, implying an absence of randomisation over the different size classes. Such a bias may be put forward for the largest modal groups (i.e. vestimentum width $>16 \mathrm{~mm}$ ) which consist of only few tubeworms. Conversely, as younger individuals are attached onto the tubes of older ones, it seems quite improbable that it could affect the smallest modal groups. Second, heterogeneity in the number of size groups may be related to the spatial variation in larval supply. However, according to our previous observations between the Genesis and Parigo vent sites, we can suppose that successive recruitment events should be synchronous at a spatial scale of about 10s of m within a site. Moreover, Kim \& Mullineaux (1998) showed that near-bottom currents induced by tides could transport larvae up to $2 \mathrm{~km}$ along the EPR during a single tidal excursion in the same vent field at $9^{\circ} 50^{\prime} \mathrm{N}$. Finally, from experiments of colonisation on artificial settlement panels, Mullineaux et al. (1998) observed at $9^{\circ} 50^{\prime} \mathrm{N}$ that the recruitment of the gastropod Lepetodrilus elevatus was spatially coherent at a scale of at least $1 \mathrm{~km}$. Thus, it is unlikely that a sampling bias or differing larval supplies at micro-spatial scales induce the lack of 1 cohort for small- and middle-size classes (i.e. vestimentum width $<16 \mathrm{~mm}$ ) despite the aggregative distribution of Riftia within a site (Jollivet 1993). However, for these organisms, the different modal components subsequently assigned to cohorts exhibit different characteristics (i.e. mean size, proportion) among samples.

Metabolism and ultimately the growth rate of Riftia are dependent upon biosynthesis by endosymbionts and should be closely related to the variability of environmental factors (Goffredi et al. 1997). Along the vestimentum width axis, differences among samples, between the location of the successive modes for small and middle-size individuals, could result from variations of the growth rate in response to local variations of the physical and chemical environment (Johnson et al. 1986, 1988). From the analysis of population structure of the polychaetes Paralvinella pandorae and $P$. palmiformis, McHugh (1989) suggested that variation in size among populations from vent to vent on the northern Pacific ridges may partly reflect growth rate variability in response to local habitat variations. Using RNA:DNA ratio measurements on the vestimentiferan tubeworm Ridgeia piscesae, De Bevoise \& Taghon (1988) observed a significant variation in the organism growth rate from individuals collected at 2 Juan de Fuca vent sites, which were separated by only $2 \mathrm{~m}$ but displayed very different environmental conditions. 
Finally, from in vivo laboratory experiments, Shillito et al. (1999) showed that the growth rate of the Riftia tube varied among individuals originating from different vent sites and could be affected by the chemical conditions of each site. In the present study, the influence of habitat characteristics on local variations of Riftia growth rates cannot be quantified due to the lack of data on environmental conditions for the 1996 and 1997 cruises.

Although the influence of small-scale spatial variations of environmental conditions on growth rate cannot be neglected, a second hypothesis may be proposed to explain the differences of the position of the successive size groups. As samples were collected over about 1 mo at a single vent site, modal differences between the 3 temporal samples could be attributable to the ageing of the different cohorts of the population. However, to be valid, this hypothesis implies that the modal size of each cohort increases between 2 successive samples. This is verified if we assume that the $1 \mathrm{st}$ component of the 3rd sample, namely from 19 December 1997 (i.e. Component 0 in Table 3) results from a massive recruitment event occurring between the 2 last samplings. In this case, the 1st component observed on 27 November and 7 December becomes the 2nd component on 19 December. According to this assumption, growth of the vestimentum width could be drawn for the 5 main cohorts (i.e. Components 1 to 5 in Table 3) over a period of $22 \mathrm{~d}$ (Fig. 6). Riftia displayed a linear growth of the vestimentum width. Vestimentum width growth rates ranged from $0.121 \mathrm{~mm} \mathrm{~d}^{-1}$ for the Cohort 1 to $0.250 \mathrm{~mm} \mathrm{~d}^{-1}$ for the Cohort 3 . The calculation of a mean growth rate equal to $0.193 \mathrm{~mm} \mathrm{~d}^{-1}$ could then be used to make some assumptions on Riftia population dynamics.

The largest individuals sampled at Riftia Field had a vestimentum width of $21.67 \mathrm{~mm}$; therefore we may

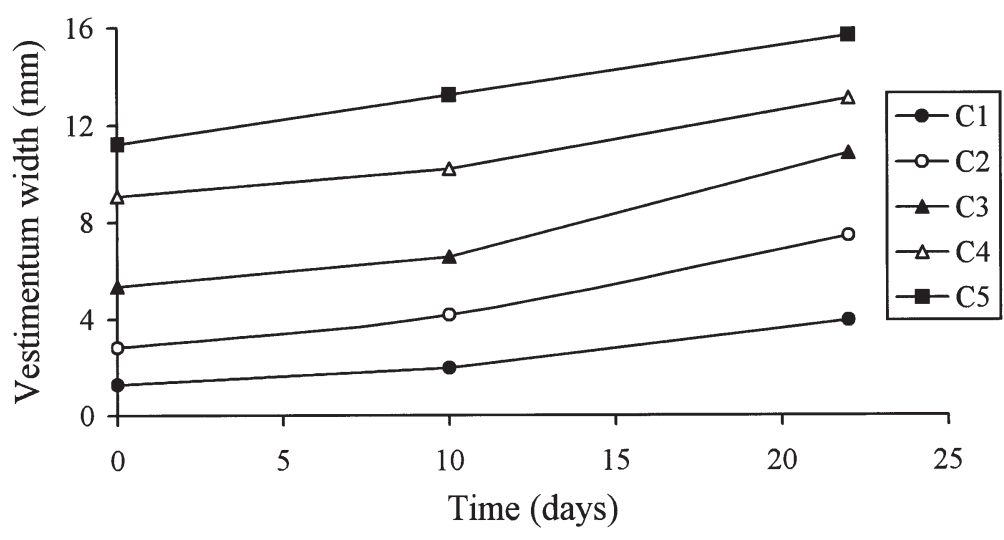

Fig. 6. Riftia pachyptila. Growth curves corresponding to each of the 5 main cohorts shared by the 3 temporal samples of Riftia Field. Growth rates are estimated from the increase of vestimentum width of each Gaussian component mean over the 3 dates. Cohorts are numbered according to Table 3 assume they were about $112 \mathrm{~d}$ old according to a mean growth rate of $0.193 \mathrm{~mm} \mathrm{~d}^{-1}$. To compare our results with previous observations on the Riftia tube growth rate, the relationship between tube length (TL) and vestimentum width (VW) was established on a subsample of individuals collected on 19 December 1997. This relationship gives the following significant regression: $\mathrm{TL}=11.316 \mathrm{VW}^{1.241}\left(\mathrm{n}=241 ; \mathrm{r}^{2}=0.926\right)$. Thus, over 112 d, Riftia could reach a tube length of $49.3 \mathrm{~cm}$ with an impressive tube growth rate of $160 \mathrm{~cm}$ $\mathrm{yr}^{-1}$ which is about twice the previous observations (i.e. $85 \mathrm{~cm} \mathrm{yr}^{-1}$ ) reported by Lutz et al. (1994) based on photographic records.

For hydrothermal vent species, the lack of growth data is generally a main barrier to infer on the periodicity of recruitment events. In the present study, the distance between 2 successive size groups ranged between 1.51 and $3.75 \mathrm{~mm}$ in the sample from 27 November, between 1.76 and $2.21 \mathrm{~mm}$ in the sample from 7 December, and between 2.24 and 3.51 $\mathrm{mm}$ in the sample from 19 December (Table 3). Although the different size groups displayed a nonequally spaced distribution which varied among samples, the spatial and temporal variability of growth rates invalidates any possible conclusion about periodicity in recruitment. However, these results suggest that successive recruitment events occurred at a high frequency, ranging from about 8 to $20 \mathrm{~d}$. This short period could explain the apparent paradox between a discontinuous recruitment and the fact that there is no evidence of periodicity in the reproductive output (Tyler \& Young 1999). Alongridge flow reversals were reported at both $13^{\circ} \mathrm{N}$ and $9^{\circ} 50^{\prime} \mathrm{N}$ field for periods of weeks (Chevaldonné et al. 1997, Kim \& Mullineaux 1998, Marsh et al. 2001) and may then be involved in the short-term variability of larval supply.

The proportions of the 1st cohorts varied greatly within and among samples. Such variations could be due to differing success in the recruitment of Riftia in response to variations of larval supply and juvenile mortality at small spatial scales. However, small individuals are the main component of Riftia populations, which is indicative of an active larval recruitment. By contrast, largest individuals (i.e. vestimentum width $>15 \mathrm{~mm}$ ), which are about $80 \mathrm{~d}$ old, constituted only a few percent of the total population. Thus, individual survivorship rate is probably very low as it was already shown among the vestimentiferans by Tunnicliffe et al. (1990). During their 26 d experiment, these authors reported that about $44 \%$ of the observed Ridgeia spp. apparently died 
because of predation and the physical instability of the environment. Assuming that our 3 samples from Riftia Field represent the temporal evolution of 1 population, our results suggest that Riftia displays a high individual growth rate and a high population turnover, which are characteristic of an opportunistic species.

Following dispersal of offspring, both the success of recruitment and the maintenance of adult populations will mostly depend on the ability of larvae to settle over new vents or on adult populations. Settlement is therefore critical and could be driven by the physical, chemical and biological conditions of the hydrothermal habitat. Concerning Riftia, several factors could induce larval settlement or ensure recruit survival. According to the physiological tolerance and the nutritional requirements of vent organisms, chemical characteristics of the habitat could play a significant role in determining the location of settlers. Thus, following the colonisation of new vents, Shank et al. (1998) reported that the presence of dense clumps of Riftia could be related to specific levels of hydrogen sulphide. Conversely, Mullineaux et al. (2000) argued that chemical preference is probably not a primary factor governing Riftia recruitment on experimental basalt blocks and suggested that Riftia settlement is facilitated by the occurrence of the tubeworm Tevnia jerichonana through a biological cue. According to the habitat selection hypothesis, 1 major result of our study is that most Riftia settlers seem to be located on the tubes of older conspecifics. While several Tevnia jerichonana were also collected in our samples, no Riftia settler has been observed on their tubes. Thus, if the presence of T. jerichonana facilitates the initial colonisation of new vent areas by Riftia, our results suggest that a physical or biological cue associated with Riftia adults or their tubes is also involved in the settlement. One likely explanation for the vestimentiferan succession is that both $T$. jerichonana and Riftia colonise the same locations as a result of different specific cues (e.g. vent chemistry, biological cues), then Tevnia dominates the assemblage as a result of an advantageous biological strategy and progressively disappears as a result of a spatial competition for food supply in which the ability to self-recruit may be crucial. From the numerous studies dedicated to the habitat selection in shallow-water marine invertebrates (see reviews Crisp 1974, Butman 1987, Pawlik 1992), different biological cues may be proposed to favour Riftia settlement that include: (1) the nature and the texture of the tube; (2) the presence of natural biofilms; and (3) attractive substances associated with conspecific recruits and adults.

To conclude, the present data combined with previous observations allow us to identify some characteristics of Riftia population dynamics: (1) recruitment is discontinuous and synchronised within a vent site; (2) recruitment events may occur at a high frequency according to short-term variability of larval supply; (3) settlement may result from habitat selection; and (4) Riftia exhibits high growth and mortality rates suggesting a high population turnover.

Acknowledgements. We gratefully acknowledge the captains and the crew of the NO 'Nadir' and RV 'Atlantis II', the members of the 'Nautile' and 'Alvin' groups. We are particularly grateful to L. Mullineaux, the chief scientist of the EPR'97 cruise, who allowed us to conduct this work. We are indebted to C. Durif, D. Eveillard and F. Not for their valuable laboratory assistance. This work was supported by the French national programme DORSALES (CNRS, INSU, IFREMER).

\section{LITERATURE CITED}

Bhattacharya CG (1967) A simple method of resolution of a distribution into Gaussian components. Biometrics 23: 115-135

Black MB, Lutz RA, Vrijenhoek RC (1994) Gene flow among vestimentiferan tube worm (Riftia pachyptila) populations from hydrothermal vents on the eastern Pacific. Mar Biol 120:33-39

Butman CA (1987) Larval settlement of soft sediment invertebrates: the spatial scales of pattern explained by active habitat selection and the emerging rôle of hydrodynamical processes. Oceanogr Mar Biol Annu Rev 25:113-165

Cary SC, Felbeck H, Holland ND (1989) Observations on the reproductive biology of the hydrothermal vent tubeworm Riftia pachyptila. Mar Ecol Prog Ser 52:89-94

Chevaldonné $\mathrm{P}$, Jollivet $\mathrm{D}$, Vangriesheim A, Desbruyères $\mathrm{D}$ (1997) Hydrothermal-vent alvinellid polychaete dispersal in the eastern Pacific. 1. Influence of vent site distribution, bottom currents, and biological patterns. Limnol Oceanogr 42:67-80

Comtet D, Desbruyères D (1998) Population structure and recruitment in mytilid bivalves from the Lucky Strike and Menez Gwen hydrothermal fields (37 $17^{\prime} \mathrm{N}$ and $37^{\circ} 50^{\prime} \mathrm{N}$ on the Mid-Atlantic Ridge). Mar Ecol Prog Ser 163: 165-177

Crisp DJ (1974) Factors influencing the settlement of marine invertebrate larvae In: Grant PT, Makie AM (eds) Chemoreception in marine organisms. Academic Press, New York, p 177-265

De Bevoise AE, Taghon GL (1988) RNA:DNA ratios of the hydrothermal-vent vestimentiferans Ridgeia piscesae and $R$. phaeophiale indicate variations in growth rates over small spatial scales. Mar Biol 97:421-426

Frontier S, Pichod-Viale D (1991) Ecosystèmes: structure, fonctionnement, évolution. Masson, Paris

Gardiner SL, Jones ML (1985) Ultrastructure of spermiogenesis in the vestimentiferan tube worm Riftia pachyptila (Pogonophora: Obturata). Trans Am Microsc Soc 104: 19-44

Goffredi S, Childress JJ, Desaulnier N, Lee R, Lallier F, Hammond D (1997) Inorganic carbon acquisition by the hydrothermal vent tubeworm Riftia pachyptila depends upon high external $\mathrm{PCO}_{2}$ and upon proton-equivalent ion transport by the worm. J Exp Biol 200:883-896

Gros P, Cochard JC (1978) Biologie de Nyctiphanes couchii 
(Crustacea, Euphausiacea) dans le secteur nord du Golfe de Gascogne. Ann Inst Océanogr Paris 54:25-46

Hasselblad V (1966) Estimation of parameters for a mixture of normal distributions. Technometrics 8:431-446

Johnson KS, Beehler CL, Sakamoto-Arnold CM, Childress JJ (1986) In situ measurements of chemical distribution in a deep-sea hydrothermal vent field. Science 231:1139-1141

Johnson KS, Childress JJ, Hessler RR, Sakamoto-Arnold CM, Beehler CL (1988) Chemical and biological interactions in the Rose Garden hydrothermal vent field, Galapagos spreading center. Deep-Sea Res 35:1723-1744

Jollivet D (1993) Distribution et évolution de la faune associée aux sources hydrothermales profondes à $13^{\circ} \mathrm{N}$ sur la dorsale du Pacifique orientale: le cas particulier des polychètes Alvinellidae. PhD thesis, Université de Bretagne Occidentale, Brest

Jollivet D (1996) Specific and genetic diversity at deep-sea hydrothermal vents: an overview. Biodiv Cons 5: 1619-1653

Jollivet D, Desbruyères D, Bonhomme F, Moraga D (1995) Genetic differentiation of deep-sea hydrothermal vent alvinellid populations (Annelida: Polychaeta) along the East Pacific Rise. Heredity 74:376-391

Jollivet D, Chevaldonné P, Planque B (1999) Hydrothermalvent alvinellid polychaete dispersal in the eastern Pacific. 2. A metapopulation model based on habitat shifts. Evolution 53:1128-1142

Jollivet D, Empis A, Baker MC, Hourdez S and 4 others (2000) Reproductive biology, sexual dimorphism, and population structure of the deep sea hydrothermal vent scale-worm, Branchipolynoe seepensis (Polychaeta: Polynoidae). J Mar Biol Assoc UK 80:55-68

Jones ML (1981) Riftia pachyptila, new genus, new species, the vestimentiferan worm from the Galapagos Rift geothermal vents (Pogonophora). Proc Biol Soc Wash 93: 1295-1313

Kim SL, Mullineaux LS (1998) Distribution and near-bottom transport of larvae and other plankton at hydrothermal vents. Deep-Sea Res II 45:423-440

Lalou C (1991) Deep-sea hydrothermal venting: a recently discovered marine system. J Mar Syst 1:403-440

Lutz RA, Jablonski D, Turner RD (1984) Larval development and dispersal at deep-sea hydrothermal vents. Science 226:1451-1454

Lutz RA, Shank TM, Fornari DJ, Haymon RM, Lilley MD, Von Damm KL, Desbruyères D (1994) Rapid growth at deepsea vents. Nature 371:663-664

Marsh AG, Mullineaux LS, Young CM, Manahan DT (2001) Larval dispersal potential of the tubeworm Riftia pachyptila at deep-sea hydrothermal vents. Nature 411:77-80

McHugh D (1989) Population structure and reproductive biology of two sympatric hydrothermal vent polychaetes, Paralvinella pandorae and P. palmiformis. Mar Biol 103: 95-106

McHugh D, Tunnicliffe V (1994) Ecology and reproductive

Editorial responsibility: Otto Kinne (Editor),

Oldendorf/Luhe, Germany biology of the hydrothermal vent polychaete Amphisamytha galapagensis (Ampharetidae). Mar Ecol Prog Ser 106:111-120

Mullineaux LS, Wiebe PH, Baker ET (1995) Larvae of benthic invertebrates in hydrothermal vent plumes over the Juan de Fuca Ridge. Mar Biol 122:585-596

Mullineaux LS, Fisher CR, Peterson CH, Schaeffer SW (2000) Tubeworm succession at hydrothermal vents: use of biogenic cues to reduce habitat selection error? Oecologia 123:275-284

Pawlik JR (1992) Chemical ecology of the settlement of benthic marine invertebrates. Oceanogr Mar Biol Annu Rev 30:273-335

Pond DW, Dixon D, Sargent J (1997) Wax-ester reserves facilitate dispersal of hydrothermal vent shrimps. Mar Ecol Prog Ser 146:289-290

Shank TM, Fornari DJ, Von Damm KL, Lilley MD, Haymon RM, Lutz RA (1998) Temporal and spatial patterns of biological community development at nascent deep-sea hydrothermal vents ( $9^{\circ} 50^{\prime} \mathrm{N}$, East Pacific Rise). Deep-Sea Res II 45:465-515

Shillito B, Ravaux J, Gaill F, Delachambre J, Thiébaut E, Childress JJ (1999) Preliminary data on carbon production of deep sea vent tubeworms. Mar Ecol Prog Ser 183:275-279

Sokal RR, Rohlf FJ (1981) Biometry, 2nd edn. WH Freeman and $\mathrm{Co}$, New York

Southward EC, Coates KA (1989) Sperm masses and sperm transfer in a vestimentiferan, Ridgeia piscesae Jones, 1985 (Pogonophora: Obturata). Can J Zool 67:2776-2781

Tomlinson PK (1971) NORMSEP: Normal distribution separation. In: Abramson NJ (ed) Computer program for fish stock assessment. FAO Fish Tech Pap 101:p.4

Tunnicliffe V (1991) The biology of hydrothermal vents: ecology and evolution. Oceanogr Mar Biol Annu Rev 29. 319-407

Tunnicliffe V, Garrett JF, Johnson HP (1990) Physical and biological factors affecting the behaviour and mortality of hydrothermal vent tubeworms (vestimentiferans). DeepSea Res 37:103-125

Tyler PA, Young CM (1999) Reproduction and dispersal at vents and cold seeps. J Mar Biol Assoc UK 79:193-208

Van Dover CL (1994) In situ spawning of hydrothermal vent tubeworms (Riftia pachyptila). Biol Bull 186:134-135

Watremez P, Kervevan C (1990) Origine des variations de l'activité hydrothermale: premiers éléments de réponse d'un modèle numérique simple. CR Acad Sci Paris Ser II 311:153-158

Young CM, Vasquez E, Metaxas A, Tyler PA (1996) Embryology of vestimentiferan tube worms from deep-sea methane/sulphide seeps. Nature 381:514-516

Zal F, Jollivet D, Chevaldonné $\mathrm{P}$, Desbruyères D (1995) Reproductive biology and population structure of the deep-sea hydrothermal vent worm Paralvinella grasslei (Polychaeta: Alvinellidae) at $13^{\circ} \mathrm{N}$ on the East Pacific Rise. Mar Biol 122:637-648

Submitted: July 4, 2001; Accepted: January 29, 2002

Proofs received from author(s): May 6, 2002 